Vol 1, No 2, Desember 2020; 132-148

e-ISSN : 2723-3324

Available at: e-journal.sttberitahidup.ac.id/index.php/jan/index

\title{
Dinamika Pendidikan Agama Kristen pada Masa Pandemi Covid-19: Analisis Kompetensi Pedagogik Yesus dalam Injil Matius
}

\author{
Victorius Wau ${ }^{1}$ \\ victoriuswauvrw03@gmail.com
}

\begin{abstract}
The period of the Covid-19 pandemic is a period of transition for the world, including in the field of education, which is the right of everyone. During the transition period, the government has decided to carry out the online teaching and learning process by using conference calls or social media. This model is now used by almost all educational institutions in Indonesia. In this case, of course, there are striking differences in the teaching and learning process, including with Christian Education. Therefore, the distance learning process of Christian Education can emulate the pedagogical competence of Jesus in Matthew's Gospel to be applied during this pandemic, so that the three educational domains (cognitive, affective and psychomotor) can be achieved properly. The method in writing this paper is descriptive qualitative, observing the book of Matthew and observing the dynamics of education during the pandemic via the internet and direct actions experienced by schools in Indonesia. The conclusion of this paper is that the teacher must imitate Jesus' pedagogy, such as: the teacher must know the character of the student, the teacher must be communicative with structured and creative material, the teacher can use the discovery learning method, the teacher must provide teaching based on the child's needs, and the teacher must continue to teach basic things in a child's life.
\end{abstract}

Keywords: Covid-19, Christian education, Jesus' pedagogy

\section{Abstrak}

Masa pandemi Covid-19 adalah masa transisi bagi dunia, termasuk di bidang pendidikan yang adalah hak setiap orang. Di masa transisi, pemerintah telah menetapkan untuk melakukan proses kegiatan belajar mengajar (KBM) secara daring dengan menggunakan conference call atau media sosial. Model ini kini digunakan hampir seluruh lembaga pendidikan di Indonesia. Dalam hal ini tentu ada perbedaan yang mencolok dalam proses KBM, tidak terkecuali dengan Pendidikan Agama Kristen (PAK). Maka dari itu, dalam proses pembelajaran PAK jarak jauh dapat meneladani kompetensi pedagogik Yesus dalam Injil Matius untuk diterapkan di masa pandemi ini, sehingga tiga ranah pendidikan (kognitif, afektif dan psikomotorik) tetap tercapai dengan baik. Metode dalam penulisan karya tulis ini adalah deskriptif kualitatif, mengamati kitab Matius dan pengamatan dinamika pendidikan di masa pandemi lewat internet dan tindakan langsung yang dialami oleh sekolah-sekolah di Indonesia. Kesimpulan dari karya tulis ini adalah guru harus meneladani pedagogik Yesus, seperti: guru harus mengenal karakter murid, guru harus komunikatif dengan materi yang terstruktur dan kreatif, guru dapat menggunakan metode discovery learning, guru harus

\footnotetext{
${ }^{1}$ Mahasiswa Sekolah Tinggi Teologi Berita Hidup
} 
memberikan pengajaran berdasarkan kebutuhan anak, dan guru harus tetap mengajarkan halhal yang mendasar dalam kehidupan anak.

Kata-kata kunci: Pendidikan Agama Kristen, Covid-19, pedagogik Yesus

\section{PENDAHULUAN}

Masa Corona Virus Desease 2019 (Covid-19) adalah masa transisi bagi masyarakat Indonesia dan mungkin menjadi masa yang sulit bagi seluruh dunia. Banyak keresahan dari masyarakat Indonesia karena dampak pandemi Covid-19. Salah satu transisi yang saat ini dialami oleh bangsa Indonesia adalah dalam hal pendidikan. Banyak sekolah yang proses belajar mengajar tidak lagi dilakukan secara tatap muka tetapi serba daring dengan menggunakan aplikasi canggih, seperti Classroom, Zoom meeting, Google form, dan lainlain. Artinya, semua lembaga pendidikan dalam proses KBM (Kegiatan Belajar Mengajar), mulai dari Pendidikan Anak Usia Dini (PAUD), Sekolah Dasar (SD), Sekolah Menengah Pertama (SMP), Sekolah Menengah Atas (SMA) dan sederajat, bahkan Perguruan Tinggi dituntut untuk mengikuti perubahan ini. Kebijakan yang diberlakukan adalah belajar di rumah. $^{2}$ Proses belajar mengajar tetap berjalan melalui kegiatan di rumah. Guru mengajar dari rumahnya masing-masing, para murid belajar di rumahnya masing-masing. Pembelajaran di rumah bisa menggunakan model pembelajaran mandiri, pembelajaran online, atau bentuk lain. ${ }^{3}$ Di masa sekarang, proses ini menjadi sebuah kebudayaan dalam pendidikan. Hal ini diterapkan sebagai salah satu bentuk kontribusi masyarakat untuk mencegah penularan Covid-19 bagi orang lain. Dengan jaga jarak akan menolong untuk memutus rantai penyebaran Covid-19.

Covid-19 juga sangat berpengaruh dalam kehidupan spiritual masyarakat, baik yang beragama Islam, Katolik, Konghucu, Budha, Hindu dan Kristen. ${ }^{4}$ Untuk itu diperlukan cara yang efektif untuk menekankan atau mengajarkan nilai-nilai keagamaan supaya masyarakat tetap memiliki sikap rohani yang baik, ${ }^{5}$ sebab spiritual yang baik akan mempengaruhi semua aspek kehidupan manusia, seperti dalam hal politik, sosial, budaya, dan lain sebagainya

2 Dian Ratu Ayu Uswatun Khasanah, Hascaryo Pramudibyanto, dan Barokah Widuroyekti, "Pendidikan Dalam Masa Pandemi Covid-19," Jurnal Sinestesia 10, no. 1 (2020): 41-48.

3 Ericha Windhiyana, "DAMPAK COVID-19 TERHADAP KEGIATAN PEMBELAJARAN ONLINE DI PERGURUAN TINGGI KRISTEN DI INDONESIA,” Perspektif Ilmu Pendidikan 34, no. 1 (2020): 1-8.

${ }^{4}$ Fransiskus Irwan Widjaja et al., "Menstimulasi Praktik Gereja Rumah di tengah Pandemi Covid19," Kurios (Jurnal Teologi dan Pendidikan Agama Kristen) 6, no. 1 (2020): 127-139.

${ }^{5}$ Yonatan Alex Arifianto, "Pentingnya Pendidikan Kristen dalam Membangun Kerohanian Keluarga di Masa Pandemi Covid-19," Regula Fidei Jurnal Pendidikan Agama Kristen 5, no. 2 (2020): 94-106. 
Secara spesifik dalam kehidupan kekristenan, bagaimana pengajaran 'Pendidikan Agama Kristen' dalam masa transisi ini? Apakah penekanan akan nilai-nilai kekristenan tetap up to date atau dirasa spiritual orang Kristen semakin memudar? Bagaimana cara yang lebih efektif untuk orang Kristen tetap memelihara dan melaksanakan ajaran-ajaran kekristenan dengan baik? Tentu sebagai anggota tubuh Kristus perlu mempelajari atau meneladani cara Yesus dalam pengajaran-Nya selama berada di dunia. Maka dari itu, penulis perlu memaparkan hasil analisis kompetensi pedagogik Yesus dalam Injil Matius untuk diterapkan oleh setiap guru, pengajar atau pendidik dalam mengajar PAK di gereja, di sekolah atau di rumah.

\section{METODE}

Metode dalam penulisan karya tulis ini adalah deskriptif kualitatif. Peneliti mengamati kitab Matius, khususnya tentang metode pembelajaran yang digunakan oleh Yesus. Peneliti juga melakukan pengamatan dinamika pendidikan di masa pandemi lewat internet dan tindakan langsung yang dialami oleh sekolah-sekolah di Indonesia. Kemudian peneliti melakukan sintesis untuk memberikan model pendidikan Agama Kristen pada masa pandemi yang sesuai dengan kebutuhan peserta didik.

\section{PEMBAHASAN}

\section{PAK pada Masa Pandemi Covid-19}

Selama pandemik ini setiap orang harus mengikuti protokol kesehatan yang dianjurkan pemerintah untuk mencegah penyebaran virus corona yang banyak sekali memakan korban. Untuk menghindari penyebaran dan memutus mata rantai penyebaran virus ini maka setiap orang harus menjaga jarak, memakai masker dan rajin mencuci tangan. Dianjurkan untuk tidak keluar rumah dan jika terpaksa harus keluar rumah karena sesuatu hal yang sangat penting maka wajib mengikuti protokol yang sudah ditetapkan oleh pemerintah.

Selama beberapa waktu pemerintah dalam hal ini menteri Pendidikan dan Kebudayaan meliburkan seluruh sekolah di Indonesia. Dimana siswa tidak memungkinkan untuk belajar di kelas bersama dengan para guru sebagaimana biasanya. Tetapi karena pandemi ini terus berkelanjutan maka dipikirkanlah cara belajar yang lain, karena pendidikan anak adalah sesuatu yang sangat penting dan harus dilanjutkan. Untuk mengatasi kondisi ini pemerintah telah berupaya mencari solusi agar pendidikan tetap bisa berlanjut di 
tengah pandemik COVID-19. Anak harus mendapatkan haknya untuk pendidikan. Situasi ini tidak bisa dibiarkan menjadi alasan untuk menghentikan pendidikan anak.

Selama masa pandemi, keadaan Indonesia dibagi dalam 4 zona, yaitu zona hitam, zona merah, zona kuning, dan zona hijau berdasarkan tingkat penyebaran virus corona. Jadi hanya zona hijau yang diberi kesempatan untuk belajar di sekolah tetapi dengan ketentuan mengikuti protokol yang telah ditetapkan. Ada pembatasan jumlah anak dan pengurangan jam belajar. Sedangkan untuk zona lain pilihannya adalah semua siswa belajar di rumah. Sosialisasi pembelajaran di rumah pun dilaksanakan kepada guru, orang tua dan murid. Pembelajaran ini kemudian disebut dengan pembelajaran di rumah (BDR) dan pembelajaran jarak jauh (PJJ). Pembelajaran di rumah dan jarak jauh menjadi solusi untuk bisa melanjutkan pendidikan karena masa pandemik Covid-19, termasuk Pendidikan Agama Kristen (PAK). Ini menjadi tugas yang tidak mudah bagi guru, murid dan orang tua. Perubahan yang secara tiba-tiba membuat semuanya gamang dan bingung, tetapi dengan arahan-arahan dari dinas maka pembelajaran jarak jauh secara pelan-pelan dapat terealisasi, sekalipun masih terus dalam pembenahan, karena menemukan banyak kendala. Pembelajaran secara daring atau secara online menjadi tren saat ini dalam dunia pendidikan. Pembelajaran daring secara virtual dengan menggunakan layanan conference call seperti Zoom, Skype, Hangout dan Youtube. Bisa juga menggunakan teknologi media sosial seperti Telegram, WhatsApp dan Facebook. Kondisi wilayah dan masyarakat Indonesia yang belum merata memiliki ponsel android atau komputer dan jaringan internet menjadi kendala. Daerah-daerah yang belum bagus jaringan internetnya dan untuk anak yang tidak memiliki ponsel android, guru-guru memiliki cara sendiri agar anak tetap bisa belajar. Orang tua mengambil materi pembelajaran dan mengumpulkan tugas anak ke sekolah dan anak belajar di rumah dengan bantuan orang tua. Materi-materi pelajaran bisa dipelajari oleh anak. Terlihat secara umum, sampai sejauh ini pembelajaran jarak jauh bisa diupayakan terlaksana.

Belajar dengan berbagai cara, strategi, dan dimana saja pun tidak masalah. Termasuk pembelajaran dengan jarak jauh dimana siswa belajar di rumah. Kendala yang kemudian muncul adalah mengingat belajar PAK maupun pelajaran lainnya harus memenuhi tiga ranah yaitu kognitif, psikomotor dan afektif. Dalam ranah ini anak harus berkembang dalam berbagai aspek yaitu aspek fisik, kognitif, sosial, emosional, spiritual, dan seni. Jika anak tidak pernah bersama dengan teman-teman di sekolah dan guru bagaimana dengan perkembangan aspek spiritual dan emosi anak? Apa yang harus dilakukan oleh guru untuk tetap bisa membina spiritual dan emosi anak? Secara kognitif anak terus mengalami perkembangannya, karena anak dibekali dengan ilmu oleh guru secara daring. Tetapi akan 
terjadi ketimpangan jika siswa hanya belajar memenuhi kognitifnya saja, sementara perkembangan aspek lain yang juga tidak kalah pentingnya menjadi masalah, yaitu perkembangan aspek spiritual dan emosi anak. Padahal untuk masa depannya anak memerlukan kestabilan emosi dalam menjalin hubungan dengan orang lain dan sebagai ciptaan Tuhan secara spritual juga harus bertumbuh. ${ }^{6}$

Pembelajaran PAK untuk pembinaan spiritual anak tidak cukup hanya sampai pada ranah kognitif saja, tetapi harus mencapai pada tahap implementasi. Pembelajaran secara Online untuk memberi pemahaman dan berbagai macam ilmu sangat memungkinkan untuk bisa tercapai. Bahkan dengan tersedianya sumber belajar di internet para murid bisa mendapatkan banyak pengetahuan. Hal yang tidak didapatkan di sana adalah tentang perkembangan sosial dan spiritual anak, karena ini tidak bisa sekadar belajar untuk memenuhi otak anak dengan pengetahuan tetapi esensinya adalah praktik keterampilan hidup. Supaya perkembangan anak dapat mencakup semua aspek hidup termasuk aspek spiritual dan emosional anak, maka diperlukan strategi yang dapat mengembangkan aspek ini.

Lalu bagaimana pembelajaran pengenalan akan Allah ini dapat dipahami oleh siswa dalam pembelajaran daring. Dengan strategi pembelajaran afektif diterapkan melalui pembiasaan, modeling, observasi, cerita firman Tuhan, dan latihan/pengalaman.

\section{Pembiasaan mengajar}

Hal ini juga dinyatakan dalam Kitab Ulangan 6:6-9, bahwa orang tua harus mengajar anak mengasihi Tuhan dalam setiap kesempatan. Keterlibatan keluarga begitu penting, hubungan kolaborasi guru dan orang tua memiliki kecenderungan paling besar untuk anak berkembang dalam berbagai aspek termasuk spiritual dan emosi. Pendidikan anak ditingkatkan jika rumah dan sekolah sebagai intensitas berbeda menjalin hubungan dan fungsi saling melengkapi. Untuk meningkatkan kolaborasi ini, guru perlu menjalin komunikasi terbuka dengan orang tua dan ketika keduanya bekerjasama akan mendukung meningkatkan pembelajaran anak ${ }^{7}$. Orang tua diarahkan bisa menceritakan pengalaman rohani mereka dengan Tuhan kepada anak, baik pengalaman yang menyenangkan maupun tidak, tetapi karena pertolongan dan kemurahan Tuhan semua bisa dilalui dan sampai hari ini semua ada karena kebaikan Tuhan.

\footnotetext{
${ }^{6}$ Oda Judithia Widianing, "Pendidikan Kristen di sekolah: Sebuah tugas Ilahi dalam memuridkan jiwa,” Jurnal Teologi Berita Hidup 1, no. 1 (2018): 78-89.

${ }^{7}$ J.K. Marjori, K.S. Anne, dan W. Alice Phipps, Kurikulum PAUD Berbasis Perkembangan Anak (Depok: Kencana, 2017), 280.
} 


\section{Observasi}

Mengenalkan Allah melalui alam semesta di mana anak tinggal. Pakar Teologi mengakui bahwa Tuhan menyatakan diri melalui dua penyataan yaitu penyataan khusus dan umum. Penyataan khusus adalah melalui Alkitab sedangkan penyataan umum adalah alam semesta ciptaan Tuhan. Semua yang ada di alam semesta ini menunjukkan kepada manusia tentang Tuhan, dengan memahami ciptaan Tuhan yang kelihatan maka seseorang belajar mengenal Allah yang tidak kelihatan. Hal ini senada dengan Mazmur 19:1-7 dan Roma 1:20. Siswa diarahkan untuk melihat lingkungan sekitar dan melihat kebesaran Tuhan di sana dan menyampaikan kepada guru hal apa yang dirasakan dan didapatkan lewat mengamati ciptaan Tuhan yang ada di sekitarnya.

\section{Latihan/pengalaman}

Disiplin rohani atau aktivitas rohani yang dilakukan untuk menjaga hubungan yang intim dengan Tuhan dan menyukakan hati Tuhan ${ }^{8}$. Disiplin rohani dapat membantu seseorang untuk terus bertekun dan menanamkan kebiasaan. Disiplin rohani yang bisa dilakukan, seperti: meyanyikan pujian kepada Tuhan, membaca dan menghafal firman Tuhan, saat teduh pribadi dan hidup bersyukur. Dengan pendekatan proyek, misalnya dalam satu minggu siswa diminta setiap hari bersyukur kepada Tuhan selama 2 minggu, membaca Alkitab tiga ayat satu hari selama sebulan, mendoakan orang tua, guru dan teman-teman sekolah setiap hari selama dua minggu. Murid menuliskan kegiatan ini sebagai laporan kepada guru, dan diminta untuk jujur menuliskan jika ada hal-hal yang terlewatkan atau tidak dilakukan.

\section{Modeling}

Melalui cerita firman Tuhan dan mengarahkan anak untuk menerapkan nilai-nilai yang tertuang dalam cerita itu. Misalnya jika cerita firman Tuhan tentang kasih, maka anak diarahkan untuk menerapkannya kepada orang-orang di dalam keluarga. Demikianlah orang-orang percaya harus menerapkan firman Tuhan dalam hidupnya.

\section{Analisis Kompetensi Pedagogik Yesus Berdasarkan Injil Matius}

\section{Hakikat Kompetensi Pedagogik}

Model kompetensi (competency model) merupakan kombinasi antara intelektual, keterampilan dan sikap yang harus ada dalam diri setiap orang, misalnya dalam hal bekerja sehingga terbentuk suatu cara kerja dan pencapaian hasil yang diinginkan. Apabila ketiga

\footnotetext{
${ }^{8}$ Patrick Morley, A Guide to Spiritual Disciplines (Malang: Gandum Mas, 2009), 22-23.
} 
ranah tersebut belum memenuhi standar yang diperlukan untuk suatu pekerjaan, maka perlu dikembangkan melalui pelatihan-pelatihan ${ }^{9}$.

Kompetensi artinya kemampuan yang didasari aspek kognitif, afektif dan psikomotorik dalam mencapai tujuan yang menjadi karakteristik seorang pendidik dalam menjalankan tugas utamanya, yakni mengajar, mendidik, membimbing, mengarahkan, melatih, menilai, dan mengevaluasi ${ }^{10}$.

Sedangkan pedagogik adalah seni dalam mengajar. Istilah ini merujuk pada model dan strategi pembelajaran. Jadi, kompetensi pedagogik meliputi pemahaman terhadap peserta didik, perancangan dan pelaksanaan pembelajaran, evaluasi hasil belajar dan pengembangan peserta didik untuk mengaktualisasikan berbagai potensi yang dimilikinya 11 .

Guru yang memiliki kompetensi pedagogik adalah pribadi yang menguasai karakteristik peserta didik, menguasai teori-teori belajar dan prinsip-prinsip pembelajaran yang mendidik. Mampu menetapkan berbagai pendekatan, strategi, metode dan teknik pembelajaran yang mendidik secara kreatif sesuai standar kompetensi guru. Guru mampu menyesuaikan metode pembelajaran dengan karakteristik peserta didik dan memotivasi mereka untuk belajar.

Yesus adalah seorang Guru. Yesus sebagai Guru memiliki tempat dimana Ia sering mengajar, salah satunya di Bait Allah (Mat. 4:23). Yesus memiliki kompetensi pedagogik yang terbaik. Dalam pelayanan-Nya, murid tidak hanya diajarkan untuk taat pada peraturan tetapi untuk taat kepada Yesus sendiri sebagai sang Guru. Karena diri Yesus adalah representasi dari kebenaran ${ }^{12}$.

Jadi, kompetensi pedagogik merupakan karunia Allah bagi setiap guru, dimana guru dapat mengenali karakter murid secara mendalam, menguasai teori belajar dan prinsipprinsip mengajar, terampil mengembangkan kurikulum, terampil menyiapkan bahan ajar, terampil membuka pelajaran, terampil bertanya, terampil melakukan penguatan, terampil mengadakan variasi, terampil menjelaskan, terampil menggunakan teknologi dan komunikasi, terampil mengelola dan menggunakan metode mengajar, terampil melakukan penilaian, dan lain-lain.

${ }^{9}$ Daud Manno, Kompetensi “Integratif” Tuhan Yesus Sebagai Guru (Jember: Sekolah Tinggi Alkitab Jember, 2019), 30.

${ }^{10}$ Undang-undang No. 15 tahun 2005 tentang Guru dan Dosen (Indonesia, 2015).

${ }^{11}$ Kunandar, Guru Profesional (Jakarta: Raja Grafindo Persada, 2007), 76.

${ }^{12}$ Manno, Kompetensi “Integratif” Tuhan Yesus Sebagai Guru, 73. 
Dengan meenguasai kompetensi pedagogik, diharapkan para guru dapat memahami murid dan melaksanakan kegiatan pembelajaran dengan strategi belajar yang baik sesuai dengan kebutuhan murid. Murid dapat menerima pelajaran lebih baik dan menyenangkan.

\section{Kompetensi Pedagogik Yesus dalam Injil Matius}

\section{Yesus Mengenal Karakter Murid}

Pengenalan akan karakter murid adalah sebuah kemampuan yang harus dimiliki oleh seorang guru. Bagaimana tidak, ketika guru mengajar tanpa mengenali karakter murid maka proses KBM tidak akan berlangsung secara baik dan menyenangkan. Sama seperti Yesus, sebagai Guru yang berkompeten Dia menguasai karakter murid-Nya. Dengan demikian, Yesus akan mengajar berdasarkan karakter yang ada, hasilnya akan ada perubahan dalam diri murid dan murid akan memiliki karakter yang baik, yang berkenan kepada-Nya. Injil Matius, sangat mencolok ke-Yahudi-annya. Penerima kitab ini dialamatkan untuk orangorang Yahudi. Bagi orang Yahudi, Hukum Taurat adalah hukum paling sakral yang wajib dipatuhi karena itu adalah Hukum Allah. Maka dari itu, Yesus memulai pengajaran-Nya dengan memberi penekanan bahwa "Aku datang bukan untuk meniadakan Hukum Taurat, akan tetapi menggenapinya" (Mat. 5:17-18). Pertama sekali, Yesus memiliki kemampuan untuk menarik perhatian murid dan membuat murid menerima akan pengajaran-Nya. Setelah pengajaran mulai diterima, inti pengajaran Yesus yang mengubahkan hidup ditegaskan. Dalam Matius 5:20, sekalipun Aku berkata Hukum Taurat adalah Hukum yang harus Kugenapi dan kalian taati, akan tetapi apabila hidup keagamaanmu tidak lebih baik dari orang-orang Farisi yang hanya sekedar mengetahui tanpa mengaktualisasikan dalam kehidupan yang nyata, maka sia-sialah akan pengenalan itu.

Dalam dunia pendidikan, aspek kognitif, afektif dan psikomotorik adalah satu kesatuan atau satu rantai yang beriringan dalam diri seorang murid dan guru. Yesus ingin menekankan bahwa jangan hanya memiliki kognitif yang bagus (mengetahui hukum taurat), memiliki psikomotorik yang baik (mampu mengajarkan hukum taurat kepada orang lain), akan tetapi tidak memiliki afektif yang baik (tidak melakukan dalam kehidupan).

Akhir dari sebuah Pendidikan Kristen adalah menghasilkan murid-murid yang bertobat dan berbalik dari jalan yang salah menuju jalan yang berkenan di hadapan Allah. Ada satu murid yang diceritakan dalam Injil Matius, dimana perspektifnya telah diubahkan oleh Tuhan tetapi murid mengambil keputusan yang salah dalam hidupnya. Guru hanya akan selalu mengungkapkan kebenaran, murid sebagai objek pendidikan dalam pengajaran harus mampu membuat keputusan, apakah pendidikan itu akan diterapkan atau tidak. Pribadi 
tersebut adalah Yudas, si pengkhianat. Yudas yang telah menjual Yesus selain menunjukkan bahwa dia hanya sekedar murid yang hidupnya tidak berubah (pengajaran masuk telinga kanan, keluar di telinga kiri). Pada akhirnya setelah menjual Yesus, Yudas sempat memiliki penyesalan diri. Artinya berada di titik pembentukan karakter. Akan tetapi, Yudas mengambil keputusan yang salah yaitu menggantung diri (Mat. 27:5).

Demikian halnya dalam pengajaran PAK jarak jauh, guru perlu memahami karakter anak melalui komunikasi atau interaksi yang baik dengan orang tua murid. Guru harus memberikan perancangan pembelajaran berdasarkan karakter anak. Dengan demikian pendidikan tentang kekristenan dapat mencapai tujuannya. Penerimaan akan model pembelajaran tersebut, murid yang harus memutuskan sendiri apakah pendidikan dari guru diterima atau tidak. Guru hanya akan melaksanakan tugasnya dalam memberikan pengajaran berdasarkan karakter murid.

\section{Yesus Mengajar Sesuai Kebutuhan Murid}

Dalam Matius 5:3-12 Yesus mengungkapkan 'ucapan bahagia' kepada murid-murid. 9 kali kata berbahagialah, 1 kali kata bersukacita dan 1 kata bergembira yang memiliki arti yang sama yakni sebuah sikap hati yang senang dan penuh damai. Kenapa Yesus perlu mengungkapkan ucapan bahagia ini? Yesus hendak membawa pikiran murid tidak hanya sekedar mengetahui kebenaran tetapi harus ada tindakan aktif dari setiap murid. Yesus ingin mengajarkan murid supaya kokoh dalam iman kepada-Nya dan menerapkan setiap firman Allah dalam kehidupan nyata. Yesus mengetahui bahwa pengajaran ini dibutuhkan oleh murid supaya dapat menjadi murid-murid yang sejati. Itulah sebabnya Yesus mengajarkan ucapan-ucapan bahagia ini.

Guru PAK tidak hanya sekedar menyampaikan materi tetapi memperhatikan setiap kebutuhan murid. Apakah murid perlu mengalami perubahan karakter? Apakah murid membutuhkan pengajaran yang kreatif? Apakah murid membutuhkan suasana kelas yang hidup? Apakah murid tidak terlalu monoton? Apakah murid menangkap materi dengan baik? Apakah murid membutuhkan pengajaran tentang parenting? Apakah murid membutuhkan pengajaran tentang iman? Apakah murid membutuhkan pengajaran tentang pergaulan yang baik? Apakah murid membutuhkan pengajaran cara menjaga hidup kudus? Apakah murid membutuhkan pengajaran tentang bagaimana menjadi murid yang taat? Seorang guru harus mampu peka dengan kebutuhan murid. 


\section{Yesus Pribadi yang Komunikatif}

Komunikatif artinya semua materi dapat tersampaikan dengan baik, sistematis dan isinya jelas. Tidak diragukan bahwa Yesus adalah teladan yang memiliki kompetensi dalam pengajaran. Hal ini terbukti dari respon setiap murid dengan memberikan pujian atas pengajaran-Nya dan mereka menjadi takjub (Mat. 7:28; 12:23; 13:54; 15:31; 22:33).

Dalam Injil Matius 5-7 'Khotbah di Bukit' hal ini sudah menyatakan dengan jelas bahwa Yesus sebagai Guru yang komunikatif. Yesus menyampaikan materi dengan sangat terstruktur, bahkan hanya dengan metode satu arah, Dia sangat menguasai materi. Kompetensi pedagogik Yesus juga terlihat ketika orang-orang Faris berusaha untuk menjerat Yesus dengan pertanyaan. Contohnya tentang membayar pajak kepada Kaisar (Mat. 22:1522). Kemudian Yesus menjawab dengan santai, mengapa engkau mencobai Aku? Berikanlah kepada Kaisar apa yang wajib kamu berikan dan kepada Allah apa yang wajib kamu berikan kepada Allah (Mat. 22:21). Selain butuh kompetensi dalam pengenalan karakter murid, sangat diperlukan kompetensi komunikatif dalam pengajaran.

Demikian hendaknya dalam dunia pendidikan masa kini, kompetensi komunikatif harus dimiliki oleh setiap guru atau pendidik. Apabila guru tidak komunikatif, maka materi tidak tersampaikan dengan baik dan murid akan merasa bingung dalam proses KBM.

\section{Yesus Menggunakan Metode Discovery Learning}

Perlu diingat bahwa metode bukanlah fokus utama. Metode boleh berubah-ubah sesuai kebutuhan anak didik, tetapi prinsip firman Allah tidak boleh berubah. Metode Discovery artinya pemahaman menemukan sendiri.

Discovery Learning merupakan pembelajaran yang menekankan pada proses mencari dan menemukan. Discovery sendiri dalam bahasa Indonesia berarti penemuan. Proses ini menuntut untuk berpikir secara kritis dalam menganalisa untuk mencari dan menemukan sendiri sebuah jawaban dari suatu masalah yang sedang dikaji atau dipelajari ${ }^{13}$.

Kelebihan dari metode Discovery Learning adalah hasil yang diperoleh akan setia dan tahan lama dalam ingatan karena prosesnya menemukan sendiri dan menyelidiki sendiri. Melalui belajar penemuan, siswa juga belajar berpikir analisis dan mencoba memecahkan sendiri masalah yang dihadapi.

Kemendikbud mengemukakan bahwa model pembelajaran penyingkapan atau penemuan (Discovery Learning) adalah memahami konsep, arti, dan hubungan melalui

13 Sajidan, Jurnal Pendidikan "Dwija Utama” (Surakarta: Forum Komunikasi Guru Pengawas Surakarta, 2008), 22. 
proses intuitif untuk akhirnya sampai kepada suatu kesimpulan. Discovery terjadi bila individu terlibat, terutama dalam penggunaan proses mentalnya untuk menemukan beberapa konsep dan prinsip. Discovery dilakukan melalui observasi, klasifikasi, pengukuran, prediksi, penentuan dan inferensi. Proses di atas disebut cognitive process sedangkan discovery itu sendiri adalah the mental process of assimilating concepts and principles in the mind $^{14}$.

Sedangkan Russefendi Bruner tokoh penemu metode discovery learning ini mengatakan, bahwa Discovery Learning dapat didefinisikan sebagai pembelajaran yang terjadi ketika murid diminta untuk mengorganisasikan sendiri, bukan karena materi disajikan dengan tuntas oleh guru ${ }^{15}$.

Dari beberapa pengertian di atas dapat disimpulkan bahwa Discovery Learning adalah metode yang berpusat pada peserta didik. Pada metode ini peserta didik berperan aktif, tidak hanya guru yang berperan aktif dalam proses KBM. Metode ini juga menekankan pada pemikiran dan penemuan peserta didik sehingga ilmu yang sudah didapatkan tidak mudah terlupakan dan juga membantu peserta didik untuk menemukan jalan keluar atau solusi dari permasalahan yang ada dan tentunya peserta didik juga akan memperoleh pengetahuan yang baru.

Discovery learning adalah salah satu metode yang dipakai Yesus untuk mengajar para murid-Nya. Yesus memakai metode discovery learning untuk mengajak para murid terlibat aktif dalam pengajaran Yesus. Yesus mau supaya pengajaran yang Dia berikan bertahan lama di pikiran mereka dan mereka mampu menemukan pengetahuan yang baru.

Ada beberapa metode discovery learning Yesus dalam Injil Matius, contohnya adalah mujizat dan perumpamaan. Yesus memakai kedua model pengajaran ini untuk mengenalkan siapa Yesus sebenarnya kepada para murid-Nya. Kedua model ini banyak ditemukan dalam Injil Matius. Injil Matius adalah Injil yang sistematis dalam model penulisannya, begitu juga dengan penulisan pengajaran Yesus semua disusun secara sistematis sesuai dengan topik yang dibahas. Hal ini dimaksudkan untuk memudahkan para pembaca mengetahui alur tentang pengajaran yang Yesus berikan. Dalam pengajaran yang Yesus ajarkan, Yesus tidak hanya menyentuh aspek afektif saja (perasaan) tetapi juga aspek kognitif (pengetahuan).

14 PG Dikdas, "MENGENAL MODEL PEMBELAJARAN DISCOVERY LEARNING," last modified 2020, https://lpmplampung.kemdikbud.go.id/detailpost/mengenal-model-pembelajaran-discoverylearning.

15 Darmadi, Pengembangan Model Metode Pembelajaran dalam Dinamika Belajar Siswa (Yogyakarta: Budi Utama, 2017), 107. 
Perumpamaan adalah peribahasa yang digunakan untuk keadaan tertentu atau menjelasakan tentang sesuatu hal yang terkandung dalam perumpamaan itu. Perumpamaan adalah salah satu model yang dipakai oleh Yesus untuk mengajar dan menyatakan siapa Yesus sebenarnya. Pengajaran Yesus menggunakan perumpamaan melatih para pendengar untuk merenungkan dan menemukan arti ajaran yang Yesus sampaikan. Yesus mau supaya pendengar juga belajar dari perumpamaan yang Yesus sampaikan, tidak hanya mendengar tetapi juga bisa diingat dan diterapkan dalam kehidupan sehari-hari karena mereka terlibat langsung dalam pengajaran Yesus.

Perumpamaan dicatat bukan sebagai bagian dari biografis Yesus yang disusun secara kronologis melainkan sebagai pesan yang menjelaskan ajaran Yesus dan relevansinya terhadap kebutuhan dunia dan jemaat. Dalam Injil Matius mempunyai sejumlah perumpamaan yang mengacu kepada datangnya kerajaan Allah pada masa depan, sehingga dapat disimpulkan pokok tersebut cukup penting bagi jemaat yang menjadi tujuan penulisan Injilnya.

Berikut daftar beberapa perumpamaan Yesus dalam Injil Matius.

1. Perumpamaan penabur

2. Lalang di antara gandum

3. Biji sesawi

4. Ragi

5. Harta terpendam

6. Hamba yang tidak mengampuni

7. Domba yang hilang

8. Pekerja di kebun anggur

9. Penggarap yang jahat

10. Perjamuan kawin

11. Hamba yang setia

12. Sepuluh gadis

13. Talenta
Matius 13:1-23

Matius 13:24-43

Matius 13:31-32

Matius 13:33-34

Matius 13:44-46

Matius 18:23-25

Matius 18:12-14

Matius 20:1-16

Matius 21:33-46

Matius 22:1-14

Matius 22:45-51

Matius 25:1-13

Matius 25:14-30

Mukjizat berasal dari bahasa Yunani semeion yang mempunyai arti yaitu suatu kejadian yang bermakna atau suatu peristiwa ajaib yang memberi pesan khusus. Artinya bukan hanya semata-mata menyatakan perbuatan keajaiban yang hendak dinyatakan, melainkan perbuatan yang memberikan suatu yang bermakna. Jadi jika dalam Alkitab 
dilaporkan tentang suatu mukjizat maka itu dapat diartikan sebagai kejadian yang khusus atau istimewa yang dibuat Allah untuk menyampaikan suatu pesan kepada umat manusia ${ }^{16}$. Guru yang kreatif adalah tidak hanya fokus pada kemampuan guru dalam mengajar tetapi mengajak murid terlibat atau berperan aktif menemukan sebuah kebenaran.

\section{Yesus Memiliki Tujuan Pencapaian}

Seorang guru harus memiliki target supaya dalam proses KBM akan mendapat hasil sesuai kebutuhan Pendidikan. Tanpa tujuan, KBM hanya akan menjadi kegiatan rutinitas, guru sekedar mendapat gaji dan murid tidak dimuridkan. "Mencerdaskan kehidupan bangsa" merupakan tujuan utama Pendidikan di bangsa Indonesia. Maka dari itu, setiap guru harus memiliki tujuan pencapaian dalam proses KBM.

Sama seperti Yesus, dalam pengajaran-Nya memiliki tujuan akhir yaitu murid menjadi pemeran yang terlibat aktif dalam menegakkan nilai-nilai kebenaran tersebut. Seperti menjadi garam dan terang dunia (Mat. 5:13-16), mimiliki pengenalan yang baik tentang Yesus sebagai Allah (Mat. 10:34-42), dan menjadi pemberita Amanat Agung yang merupakan tugas utama setiap orang percaya (Mat. 28:19-20). Menjadi garam dan terang artinya murid dapat menunjukkan teladan-teladan yang baik, dalam perkataan suka menggunakan kata-kata profetik (yang membangun), hidup kudus dan taat pada perintahperintah Tuhan. Pengenalan akan Allah adalah kepuasan utama dalam kehidupan setiap orang percaya karena dengan pengenalan yang baik akan menunjang kualitas iman seorang murid.

Guru tidak boleh hanya memikirkan 'materi harus diselesaikan'. Setiap guru memiliki silabus atau kontrak pembelajaran, akan tetapi tujuan utama Pendidikan tidak akan terlaksana dengan baik apabila tidak ada hasil atau pencapaian dalam diri seorang murid. Jadikan murid sebagai pribadi yang memiliki karakter yang baik, memahami materi dengan baik dan pada akhirnya representasi dari pengajaran kebenaran.

\section{Yesus Mengajar Hal-Hal Yang Mendasar}

Hal-hal mendasar yang dimaksud adalah beberapa pokok pengajaran yang harus ditekankan kepada murid sebagai ciri khas dari orang percaya. Contohnya, hal berdoa, hal memberi sedekah, hal menghakimi, hal berpuasa, hal mengumpulkan harta, hal kekuatiran, hal yang kudus dan berharga, hal pengabulan doa, jalan yang benar, hal pengajaran yang sesat, dua macam dasar yang terdapat dalam Matius 6-7. Pengajaran ini merupakan hal-hal

\footnotetext{
${ }^{16}$ Marulak Pasaribu, Eksposisi Injil Sinoptik, Revisi. (Malang: Gandum Mas, 2019).
} 
mendasar yang harus diketahui oleh para murid. Pengajaran ini harus dimiliki oleh setiap murid apabila mengaku sebagai murid Yesus. ${ }^{17}$

Demikian dalam pengajaran PAK pada masa kini, guru harus mampu memberi pengajaran tentang hal-hal mendasar. Contohnya tentang berdoa, tentang beribadah, tentang ketaatan, tentang berpuasa, tentang persepuluhan, tentang pengajaran yang sesat, tentang kekudusan, tentang Amanat Agung dan lain-lain. Guru tidak boleh hanya berekspetasi tinggi kelak murid mampu menjadi PNS, Kementerian Agama, dan lain-lain tanpa ada pengajaran mendasar yang harus dimiliki oleh seorang pengikut Kristus. Pengajaran-pengajaran mendasar ini menjadi pegangan bagi setiap orang Kristen dalam menjalani kehidupan, sehingga kelak apapun profesinya mampu mengamalkan nilai-nilai kekristenan dimanapun dan kapanpun.

\section{Relevansi Pedagogik Yesus dalam Injil Matius bagi Guru PAK pada Masa Pandemi Covid-19}

Pertama, mengenal karakter murid. Untuk sebagian angkatan, guru telah mengenal karakter murid yang masih mengalami KBM tatap muka. Akan tetapi, bagaimana dengan murid baru yang baru masuk SD, SMP, SMA, dan Perguruan Tinggi? Guru belum tentu mengenal bagaimana kebiasaan belajar mereka dan lain sebagainya. Maka dari itu, guru atau dosen PAK masa kini perlu mengenal murid dengan cara sering konsultasi dan membangun relasi dengan orang tua murid. Hal ini lah yang terjadi di masa pandemik Covid-19, guru perlu membangun hubungan yang baik dengan orang tua murid untuk mendapatkan laporan pembelajaran murid selama belajar di rumah.

Kedua, Guru juga harus mengetahui kebutuhan murid. Banyak guru PAK sekarang ini sering memberikan edukasi tentang "kuat di masa pandemi”. Hal ini akan menolong murid untuk tidak stress dan menjaga kestabilan emosi dari murid.

Ketiga, guru harus komunikatif. Dengan kondisi sekarang dimana guru atau dosen mengajar dengan teleconference call atau dengan media sosial, maka pengajar perlu memiliki kompetensi komunikatif. Pengajar harus mempersiapkan materi dengan baik dan mampu menjelaskan materi dengan jelas, menarik dan menggunakan bahasa yang tidak ambigu. Guru juga harus bisa menjawab pertanyaan-pertanyaan yang diajukan oleh murid sehingga murid mendapatkan kepuasan dalam belajar, ketika mendapatkan jawaban yang menguatakan dari guru. Hal ini akan menunjang kemampuan murid dalam menangkap informasi dari guru dan aktif dalam kegiatan belajar mengajar.

\footnotetext{
${ }^{17}$ Widianing, "Pendidikan Kristen di sekolah: Sebuah tugas Ilahi dalam memuridkan jiwa."
} 
Keempat, menggunakan metode Discovery Learning. Hal ini sangatlah relevan dalam PAK di masa pandemik. Untuk tetap memperkenalkan Allah kepada murid, murid dapat menemukan sendiri lewat alam semesta sebagai salah satu objek ciptaan Tuhan. Dengan murid belajar Alkitab juga akan menolong murid memiliki spiritual yang baik. Banyak guru yang menggunakan mtode ini. ${ }^{18}$ Guru memberikan pertanyaan kemudian murid akan berusaha menemukan jawabannya sendiri. Hal ini mungkin dirasa sulit bagi murid, akan tetapi memiliki dampak positif yang besar bagi masa depan murid karena akan lebih mengingat dalam jangka waktu yang lama. Akan tetapi, bagaimanapun guru harus memperhitungkan kapasitas murid. Memberikan tugas untuk murid temukan sendiri bukan berarti memberikan tugas sebanyak mungkin. Hal itu akan berdampak buruk bagi perkembangan mental anak dan mengurangi semangat belajar anak.

Kelima, guru juga harus memiliki tujuan pencapaian. Guru harus rutin memberikan surat evaluasi dari murid atas pembelajaran jarak jauh. Hal ini bertujuan untuk melihat bagaimana perkembangan anak. Guru harus meminta laporan untuk melihat pencapaian murid. Apabila laporan dari murid memiliki tingkat pencapaian yang memuaskan, maka guru akan terus mempertahankan cara mengajarnya. Akan tetapi, apabila murid tidak mendapat apa-apa, maka guru perlu melakukan evaluasi.

Keenam, guru juga harus tetap mengajarkan hal-hal yang mendasar seperti hal berdoa, memuji Tuhan, membaca Firman Tuhan, mengasihi sesama, dan lain sebagainya. Ini akan menolong murid tetap membangun hubungan yang intim dengan Tuhan dan menjadi pelaku firman Tuhan.

\section{KESIMPULAN}

Dalam masa sekarang ini, banyak orang sering berargumen tentang Pendidikan di masa pandemi Covid-19. Beberapa pendapat menyetujui dengan sekolah/perkuliahan daring dengan alasan "itulah perkembangan zaman". Beberapa orang yang tidak setuju mengatakan "tidak efektif mencerdaskan kehidupan bangsa". Khususnya di desa-desa atau daerah terpencil, mereka menganggap bahwa masa Covid-19 adalah masa-masa yang sulit dalam hidup mereka, terkhusus bagi anak-anak yang sedang menempuh pendidikan formal. Pendidikan adalah hak anak.

Kementerian Pendidikan dan Kebudayaan menetapkan untuk menerapkan sekolah daring, dengan menggunakan layanan conference call seperti Zoom, Skype, Hangout dan

18 Adi Putra Anggara, "Pengembangan Media Pembelajaran Powerpoint Untuk Meningkatkan Kognitif dan Kemampuan Sosial Anak Usia Dini," Jurnal Teologi Berita Hidup 2, no. 1 (2019): 11-19. 
Youtube. Bisa juga menggunakan teknologi media sosial seperti Telegram, WhatsApp dan facebook. Dengan metode daring, anak sekolah dibekali dengan kognitif sementara aspek lain seperti spiritual dan emosi terabaikan. Maka dari itu, PAK harus mengambil tindak lanjut untuk menangani masalah ini dengan tujuan memenuhi kebutuhan anak secara spiritual dan emosi.

Guru sangat berperan dalam mengupayakan cara supaya pendidikan anak secara kognitif, afektif dan psikomotorik terpenuhi. Setiap pengajar perlu meneladani pedagogik Yesus, yaitu guru harus mengenal karakter murid, guru harus komunikatif dengan materi yang terstruktur dan kreatif, guru dapat menggunakan metode discovery learning, guru harus memberikan pengajaran berdasarkan kebutuhan anak, dan guru harus tetap mengajarkan halhal yang mendasar dalam kehidupan anak.

\section{REFERENSI}

Anggara, Adi Putra. "Pengembangan Media Pembelajaran Powerpoint Untuk Meningkatkan Kognitif dan Kemampuan Sosial Anak Usia Dini." Jurnal Teologi Berita Hidup 2, no. 1 (2019): 11-19.

Arifianto, Yonatan Alex. "Pentingnya Pendidikan Kristen dalam Membangun Kerohanian Keluarga di Masa Pandemi Covid-19." Regula Fidei Jurnal Pendidikan Agama Kristen 5, no. 2 (2020): 94-106.

Darmadi. Pengembangan Model Metode Pembelajaran dalam Dinamika Belajar Siswa. Yogyakarta: Budi Utama, 2017.

Khasanah, Dian Ratu Ayu Uswatun, Hascaryo Pramudibyanto, dan Barokah Widuroyekti. "Pendidikan Dalam Masa Pandemi Covid-19." Jurnal Sinestesia 10, no. 1 (2020): $41-48$.

Kunandar. Guru Profesional. Jakarta: Raja Grafindo Persada, 2007.

Manno, Daud. Kompetensi “Integratif” Tuhan Yesus Sebagai Guru. Jember: Sekolah Tinggi Alkitab Jember, 2019.

Marjori, J.K., K.S. Anne, dan W. Alice Phipps. Kurikulum PAUD Berbasis Perkembangan Anak. Depok: Kencana, 2017.

Morley, Patrick. A Guide to Spiritual Disciplines. Malang: Gandum Mas, 2009.

Pasaribu, Marulak. Eksposisi Injil Sinoptik. Revisi. Malang: Gandum Mas, 2019.

PG Dikdas. "MENGENAL MODEL PEMBELAJARAN DISCOVERY LEARNING.” Last modified 2020. https://lpmplampung.kemdikbud.go.id/detailpost/mengenal-modelpembelajaran-discovery-learning.

Sajidan. Jurnal Pendidikan “Dwija Utama." Surakarta: Forum Komunikasi Guru Pengawas Surakarta, 2008.

Widianing, Oda Judithia. "Pendidikan Kristen di sekolah: Sebuah tugas Ilahi dalam memuridkan jiwa.” Jurnal Teologi Berita Hidup 1, no. 1 (2018): 78-89.

Widjaja, Fransiskus Irwan, Candra Gunawan Marisi, T. Mangiring Tua Togatorop, dan Handreas Hartono. "Menstimulasi Praktik Gereja Rumah di tengah Pandemi Covid19." Kurios (Jurnal Teologi dan Pendidikan Agama Kristen) 6, no. 1 (2020): 127139. 
Windhiyana, Ericha. "DAMPAK COVID-19 TERHADAP KEGIATAN PEMBELAJARAN ONLINE DI PERGURUAN TINGGI KRISTEN DI INDONESIA." Perspektif Ilmu Pendidikan 34, no. 1 (2020): 1-8.

Undang-undang No. 15 tahun 2005 tentang Guru dan Dosen. Indonesia, 2015. 